Continental impact on marine boundary layer coarse particles over the Atlantic Ocean between Europe and Antarctica

Niemi, J. V.

Elsevier

2005

Niemi, J. V. et al. 2005. Continental impact on marine boundary layer coarse particles over pÿthe Atlantic Ocean between Europe and Antarctica. Atmospheric Research 75: 301321.

http://hdl.handle.net/1975/463

Downloaded from Helda, University of Helsinki institutional repository.

This is an electronic reprint of the original article.

This reprint may differ from the original in pagination and typographic detail.

Please cite the original version. 


\title{
Continental impact on marine boundary layer coarse particles over the Atlantic Ocean between Europe and Antarctica
}

\author{
Jarkko V. Niemia, ${ }^{\text {a,b,* Heikki Tervahattu }}{ }^{\text {a,c }}$, Aki Virkkula ${ }^{\mathrm{d}}$, \\ Risto Hillamo ${ }^{\mathrm{d}}$, Kimmo Teiniläd, Ismo K. Koponen ${ }^{\mathrm{e}}$, \\ Markku Kulmala $^{\mathrm{e}}$ \\ ${ }^{a}$ Department of Biological and Environmental Sciences, University of Helsinki, P.O. Box 27, \\ FIN-00014 Helsinki, Finland \\ ${ }^{\mathrm{b}}$ Nordic Envicon Ltd., Koetilantie 3, FIN-00790 Helsinki, Finland \\ ${ }^{\mathrm{c}}$ Cooperative Institute for Research in Environmental Sciences, University of Colorado, \\ Campus Box 216, Boulder, CO 80309, USA \\ ${ }^{\mathrm{d}}$ Finnish Meteorological Institute, Air Quality Research, Sahaajankatu 20E, FIN-00880 Helsinki, Finland \\ ${ }^{\mathrm{e}}$ Department of Physical Sciences, Division of Atmospheric Sciences, University of Helsinki, \\ P.O. Box 64, FIN-00014 Helsinki, Finland
}

Received 1 July 2004; received in revised form 24 January 2005; accepted 24 January 2005

\begin{abstract}
Aerosol samples were collected in the Atlantic marine boundary layer between the English Channel and Antarctica during November-December 1999. The composition of coarse (aerodynamic diameter $\sim 1-3 \mu \mathrm{m}$ ) individual aerosol particles was studied using the SEM/EDX method. The major particle types observed were fresh sea salt, sea-salt particles reacted partly or totally with sulphuric acid or nitric acid, Mg-sulphate, Ca-sulphate, mixed aluminosilicates and sea salt, aluminosilicates, Ca-rich particles and Fe-rich particles. The relative fractions of sea-salt particles with moderate or strong $\mathrm{Cl}$ depletion were high near the coasts of Europe (65-74\%) and Northern Africa (44-87\%), low far from the coast of Western Africa (10-20\%) and very low in remote sea areas between Africa and Antarctica ( $1 \%)$. The $\mathrm{Cl}$ depletion was strongest when air masses arrived
\end{abstract}

\footnotetext{
* Corresponding author. Department of Biological and Environmental Sciences, University of Helsinki, P.O. Box 27, FIN-00014 Helsinki, Finland. Tel.: +358 9 19158841; fax: +358 919158462.

E-mail address: jarkko.v.niemi@helsinki.fi (J.V. Niemi). 
from the direction of anthropogenic pollution sources. The fractions of Mg-sulphate particles were high (18-25\%) in 2 samples near Europe. The Mg-sulphate particles were probably formed as a result of fractional recrystallization of sea-salt particles in which $\mathrm{Cl}$ was substituted by sulphate. It remained unclear whether these particles were formed in the atmosphere or during and after sampling. The relative fractions of particles from continental sources were quite low (10-15\%) near Europe, very high (25-78\%) near the coast of Northwestern Africa and very low in the remote sea areas $(0-2 \%)$. Most of the continental particles were aluminosilicates and some of them were internally mixed with sea salt. Near the coast of Northwestern Africa, the main source of aluminosilicates was Saharan dust, and near the Gulf of Guinea, emissions from biomass burning were also mixed with aluminosilicates and sea salt.

(C) 2005 Elsevier B.V. All rights reserved.

Keywords: Individual particle analysis; Marine aerosols; $\mathrm{Cl}$ depletion; Fractional recrystallization; Continental sources; Saharan dust

\section{Introduction}

Large amounts of various aerosol particles and their precursor gases originate from continental sources, and significant fractions of these emissions are transported over oceans (Husar et al., 1997; Kaufman et al., 2002; Prospero et al., 2002). In the marine boundary layer, the continental particles are mixed with marine particles, and particles and gases from both sources may react via different heterogeneous pathways (Andreae et al., 1986; Dentener et al., 1996; Song and Carmichael, 1999; Laskin et al., 2003). The differences in continental emission sources and in meteorological conditions strongly affect composition, mixture state, concentration and size of different particle types observed over oceans, especially near coasts (Carrico et al., 2003; Zhang et al., 2003). These are essential factors related to climatic impacts of aerosols (IPCC, 2001), and to other environmental impacts such as transport of nutrients and toxic compounds to oceans with continental aerosols. The deposition of continental particles is strongest near coast, where the biological activity is also especially high.

The properties and sources of aerosols over the eastern Atlantic Ocean have been studied using satellite observations and taking measurements on flights, voyages and islands (Husar et al., 1997; Chiapello et al., 1999; Raes et al., 2000; Kaufman et al., 2002; Prospero et al., 2002; Tanre et al., 2003). The chemical composition of the collected bulk or size-segregated aerosol samples has mostly been studied with different bulk chemical methods. Over the eastern Atlantic Ocean, few studies have been undertaken using individual particle analysis methods. These studies were conducted mainly near Europe (Rojas and Van Grieken, 1992; Hoornaert et al., 1996; Ebert et al., 2000, 2002) and the Canary Islands (Pósfai et al., 1995; Hoornaert et al., 2003; Li et al., 2003a), and to our knowledge, no individual particle study has been conducted previously on a voyage between the Canary Islands and Antarctica. The use of individual particle methods may provide more detailed information on the chemical composition, mixing state and morphology of particles.

Different properties of aerosols were measured during a voyage over the Atlantic Ocean between the English Channel and Antarctica in March-November 1999. The particle 
number size distributions and concentrations were presented by Koponen et al. (2002). The chemical mass concentrations and size distributions analysed with bulk methods will be presented by Virkkula et al. (submitted for publication-a,b). In our study, the composition of individual aerosol particles was investigated in the size range of $\sim 1-3 \mu \mathrm{m}$ (aerodynamic diameter) which is the fraction of coarse particles with the slowest removal from the atmosphere. We describe major particle types observed during the voyage, investigate the impact of different continental emissions on the composition of marine aerosols and examine the relative amounts and sources of continental particles. The results are compared with other individual particle and bulk aerosol measurements performed in other studies.

\section{Materials and methods}

The aerosol particles were collected on board the research vessel Akademic Fedorov as a part of the FINNARP (Finnish Antarctic Research Programme) 1999-2000 expedition. Fig. 1 shows the route of the voyage, number codes and dates of collected particle samples and backward trajectories arriving at the $1000 \mathrm{~m}$ level. The measurements were taken between the English Channel $\left(50.38^{\circ} \mathrm{N}, 00.67^{\circ} \mathrm{W}\right)$ and Cape Town during 8-25 November 1999 and between Cape Town and the coast of Antarctica $\left(70.10^{\circ} \mathrm{S}, 05.28^{\circ} \mathrm{E}\right)$ during $1-8$ December 1999. The particles were collected using a high-volume sampler with $240 \mathrm{~mm}$ quartz filters (Munktell MK 360). The flow rate of the sampler was $120 \mathrm{~m}^{3} \mathrm{~h}^{-1}$, the cut-off size $\left(\mathrm{D}_{50}\right)$ of the inlet was approximately $3 \mu \mathrm{m}$ (aerodynamic diameter) (Virkkula et al., submitted for publication-a) and sampling time was $24 \mathrm{~h}$. Virkkula et al. (submitted for publication-a) studied these same samples using bulk chemical methods. The details of sampling times, coordinates, wind speeds and directions, backward trajectories arriving at the $500 \mathrm{~m}$ level, ambient and sample flow temperatures and relative humidities (RHs) are shown in their article. Some of the bulk chemical results of Virkkula et al. (submitted for publication-a,b) were also used in this work.

The elemental composition and size of individual particles were investigated using a scanning electron microscope (SEM-ZEISS DSM 962) coupled with an energy dispersive X-ray microanalyser (EDX-LINK ISIS with the ZAF-4 measurement program). The SEM/ EDX samples were prepared by pressing a tape (Scotch Ruban Adhesive) attached to an aluminium plate onto the filter surface covered with particles. Then samples were coated with carbon (BAL-TEC CED 030 Carbon Evaporator) to make the sample surface conductive. The SEM/EDX was operated at $20 \mathrm{kV}$ accelerating voltage, and counting time of X-ray spectrum was $15 \mathrm{~s}$. The total count rate was calibrated to 1500 count per second with cobalt. The number of particles investigated was 100 (samples 1-10 and 18) or 50 (samples 11-17 and 19-23) from each sample. The sample size in the SEM/EDX analysis was considered large enough to show variation in major particle types in different samples (Breed et al., 2002; Kupiainen et al., 2003).

The minimum geometric diameter of the analysed particles was $1 \mu \mathrm{m}$, and $60 \%$ of the particles were smaller than $2 \mu \mathrm{m}, 90 \%$ smaller than $3 \mu \mathrm{m}$ and $99 \%$ smaller than $6 \mu \mathrm{m}$. The $\mathrm{D}_{50}$ of the inlet was approximately $3 \mu \mathrm{m}$ (aerodynamic diameter), and the presence of particles with geometric diameter $>3 \mu \mathrm{m}$ can be explained by the smooth collection 
Sample numbers and locations

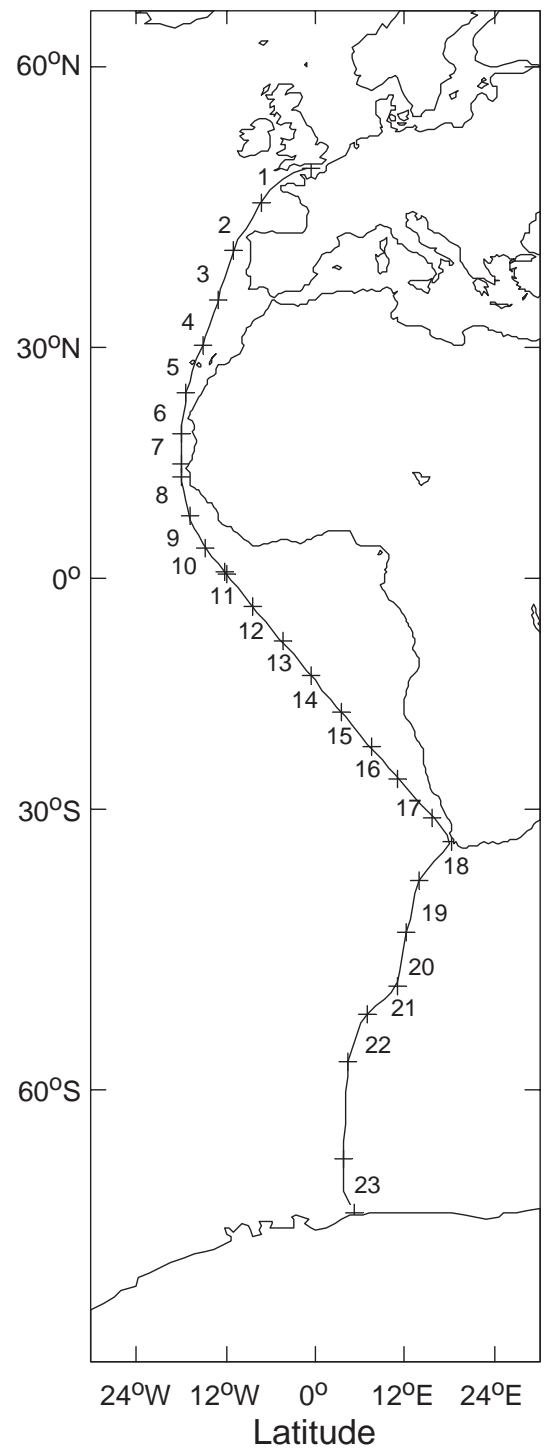

Backtrajectories arriving at $1000 \mathrm{~m}$

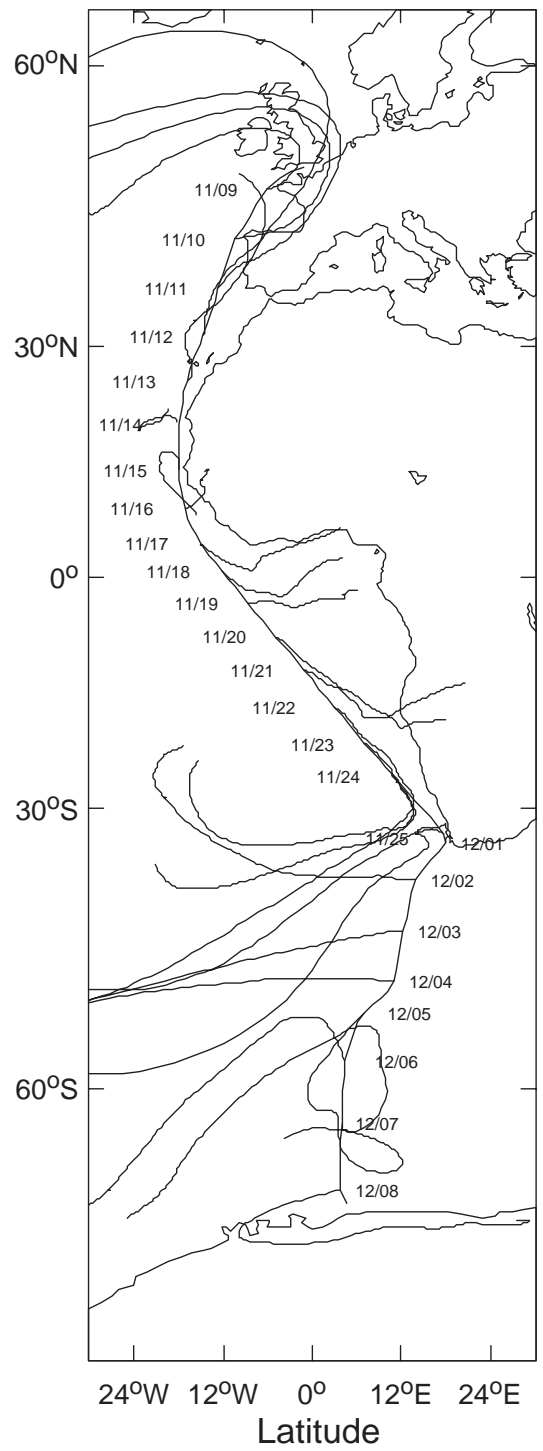

Fig. 1. Voyage route, locations of the sample change places (sample numbers 1-23) and 5-day backward trajectories arriving at the $1000 \mathrm{~m}$ level above the location of the ship.

efficiency curve of the inlet and by the flat and angular shapes of some particles. The preparation process of SEM/EDX samples may have slightly favoured large particles since they do not penetrate as deep inside the filter material as the smallest particles. However, the size fraction (aerodynamic diameter $\sim 1-3 \mu \mathrm{m}$ ) studied was so narrow that this possible bias in particle sizes (and types) was probably negligible. 
The elemental weight percentages of individual particles were calculated using ZAF-4 correction for the following elements: $\mathrm{Na}, \mathrm{Mg}, \mathrm{Al}, \mathrm{S}, \mathrm{Cl}, \mathrm{K}, \mathrm{Ca}$, Ti and Fe. The ZAF correction method is ideal for flat homogenous samples. The highly variable sizes and shapes of the particles reduce the accuracy of the ZAF-corrected elemental results. However, the accuracy was sufficient to identify different particle types and to compare the differences in elemental ratios of the same particle type in different samples (Gao and Anderson, 2001; Breed et al., 2002; Paoletti et al., 2002; Kupiainen et al., 2003; Zhang et al., 2003).

Backward trajectories were calculated using the vertical motion model in the HYSPLIT4 (HYbrid Single-Particle Lagrangian Integrated Trajectory) model (Draxler and Rolph, 2003) with the FNL meteorological database at NOAA Air Resources Laboratory's web server (Rolph, 2003). The NAAPS (Navy Aerosol Analysis and Prediction System) model results were used to determine the optical depths and distribution of dust, smoke and sulphate aerosols near the coast of Africa. Details of the model and model results are available at the internet pages (http://www.nrlmry.navy.mil/ aerosol/) of the Naval Research Laboratory, Monterey, California.

\section{Results and discussion}

\subsection{Particle types}

The analysed particles were classified into 7 particle types based on their elemental composition. Table 1 shows the particle types, classification criteria and mean elemental weight ratios of the particle types. The particle types and classification criteria were selected based on (1) typical elemental combinations observed in the analysed particles and (2) the characteristics of different particle types observed in other studies (e.g. Xhoffer et al., 1991; Ebert et al., 2002; Li et al., 2003a; Reid et al., 2003). Sea-salt particles (SSPs)

Table 1

Classification criteria and mean elemental weight ratios of particle types

\begin{tabular}{|c|c|c|c|c|c|c|c|c|c|c|c|}
\hline \multirow[t]{2}{*}{ Particle type } & \multirow{2}{*}{$\begin{array}{l}\text { Elemental classification } \\
\text { criteria }\end{array}$} & \multicolumn{9}{|c|}{ Mean elemental weight ratios of particle types } & \multirow[t]{2}{*}{$\mathrm{n}^{\mathrm{a}}$} \\
\hline & & $\mathrm{Na}$ & $\mathrm{Mg}$ & $\mathrm{Al}$ & $\mathrm{S}$ & $\mathrm{Cl}$ & $\mathrm{K}$ & $\mathrm{Ca}$ & $\mathrm{Ti}$ & $\mathrm{Fe}$ & \\
\hline Sea salt & $\begin{array}{l}(\mathrm{Na}+\mathrm{Cl})>30 \text { and }(\mathrm{Mg}+\mathrm{K}+\mathrm{Ca}) \\
<25 \text { and } \mathrm{Al}<3\end{array}$ & 36 & 5 & $<1$ & 7 & 48 & 1 & 1 & $<1$ & $<1$ & 1064 \\
\hline Mg-sulphate & $\mathrm{Mg}>20$ and $\mathrm{S}>25$ & 4 & 30 & $<1$ & 58 & $<1$ & 5 & $<1$ & $<1$ & $<1$ & 59 \\
\hline Ca-sulphate & $\mathrm{Ca}>25$ and $\mathrm{S}>20$ & 5 & 1 & 2 & 39 & 2 & 2 & 47 & $<1$ & 2 & 83 \\
\hline $\begin{array}{l}\text { Mixed aluminosilicates } \\
\text { and sea salt }\end{array}$ & $\begin{array}{l}\mathrm{Al}>3 \text { and }[(\mathrm{Na}>20 \text { and } \\
\mathrm{Na} / \mathrm{Al}>1) \text { or } \mathrm{Cl}>10]\end{array}$ & 22 & 10 & 21 & 11 & 15 & 7 & 4 & 1 & 11 & 147 \\
\hline Aluminosilicates & $\begin{array}{l}(\mathrm{Al}>15 \text { and } \mathrm{Na} / \mathrm{Al}<1 \text { and } \\
\mathrm{Cl}<10 \text { and } \mathrm{Fe}<60) \text { or } \mathrm{Ti}>15\end{array}$ & 9 & 8 & 38 & 7 & 3 & 11 & 3 & 2 & 19 & 295 \\
\hline Ca-rich & $\mathrm{Ca}>60$ & 2 & 1 & $<1$ & 7 & 1 & 2 & 86 & $<1$ & $<1$ & 3 \\
\hline Fe-rich & $\mathrm{Fe}>60$ & 7 & 4 & 5 & 2 & 2 & 1 & $<1$ & 1 & 77 & 13 \\
\hline Other & - & 17 & 17 & 3 & 29 & 10 & 7 & 13 & 1 & 3 & 36 \\
\hline
\end{tabular}

Elemental weight ratios are semiquantitative and normalized to $100 \%$.

${ }^{\text {a }}$ Number of analysed particles. 
contained abundant $\mathrm{Na}$ and minor amounts of $\mathrm{Mg}, \mathrm{Ca}$ and $\mathrm{K}$. The amounts of $\mathrm{Cl}$ and $\mathrm{S}$ varied strongly, depending on the rate of $\mathrm{Cl}$ substitution. $\mathrm{S}$ is considered to be an indicator of sulphate, since it was mainly in the form of sulphates during the voyage, according to ion chromatography (IC) analysis (Virkkula et al., submitted for publication-a). The SSPs also contained different mixed-cation sulphates and chlorides, in which the amounts of $\mathrm{Mg}, \mathrm{K}$ or $\mathrm{Ca}$ were higher or lower compared with the ratios of these elements and $\mathrm{Na}$ in seawater. The marine crystallization products that deviated most from the SSPs were classified as other particle types ( $\mathrm{Mg}$-sulphate and $\mathrm{Ca}$-sulphate) or were left in the unclassified ('others') particle group. The particles in the $\mathrm{Mg}$-sulphate group contained abundant $\mathrm{Mg}$ and $\mathrm{S}$ and also often minor amounts of $\mathrm{Na}$ and/or $\mathrm{K}$. The particles of the $\mathrm{Ca}-$ sulphate group contained abundant $\mathrm{Ca}$ and $\mathrm{S}$, and minor amounts of other elements were also detected in some particles.

The particles that contained common elements of crustal rock ( $\mathrm{Al}, \mathrm{Fe}$ and/or $\mathrm{Ti}$ ) were termed aluminosilicates, since practically all of these particles (except a few Ti-rich particles) also contained abundant Si. This was confirmed by analysing the Si contents of particles that were located far from the quartz filter fibres. Other studies also showed that the presence of $\mathrm{Al}$ in particles indicates that they almost always contain Si (Rojas and Van Grieken, 1992; Ebert et al., 2000; Hoornaert et al., 2003; Reid et al., 2003). The mixed aluminosilicates and sea salt were characterized with the common elements of aluminosilicates ( $\mathrm{Al}, \mathrm{Fe}$ and/or $\mathrm{Ti}$ ) and sea salt ( $\mathrm{Na}$ and/or $\mathrm{Cl}$ ). Fe-rich particles contained abundant $\mathrm{Fe}$ and $\mathrm{Ca}$-rich particles abundant $\mathrm{Ca}$. Finally, we formed the group 'others' for the remaining particles that did not belong to any of the particle groups mentioned above. This group contained mainly different sulphates (abundant $\mathrm{S}$ and some $\mathrm{Na}, \mathrm{Mg}, \mathrm{Ca}$ and/or $\mathrm{K}$ ) and also some chlorides (abundant $\mathrm{Cl}$ and some $\mathrm{Na}, \mathrm{Mg}, \mathrm{Ca}$ and/ or K). Table 2 shows the relative percentages of different particle types in each sample during the voyage. In most samples, the SSP fractions were clearly predominant compared with other particle types. However, the fractions of continental particles, such as aluminosilicates and Fe-rich particles, were predominant near the coast of Africa (samples 7-11).

\subsection{Marine particles}

\subsubsection{Chlorine depletion from SSPS}

The amounts of $\mathrm{Cl}$ and $\mathrm{S}$ varied strongly in SSPs, depending on the rate of $\mathrm{Cl}$ substitution. Anions of strong acids such as nitrate and sulphate are usually the most important chloride-substituting compounds (Kerminen et al., 1998; Mouri et al., 1999; Ro et al., 2001; Li et al., 2003a). The IC results of Virkkula et al. (submitted for publication-b) showed that sulphate and nitrate explained nearly all of the $\mathrm{Cl}$ depletion during this voyage. The net reactions of these Cl-substituting acidic compounds are

Sulphuric acid: $2 \mathrm{NaCl}(\mathrm{s})+\mathrm{H}_{2} \mathrm{SO}_{4}(\mathrm{~g}) \leftrightarrow \mathrm{Na}_{2} \mathrm{SO}_{4}(\mathrm{~s})+2 \mathrm{HCl}(\mathrm{g})$

(Reaction 1)

Nitric acid: $\mathrm{NaCl}(\mathrm{s})+\mathrm{HNO}_{3}(\mathrm{~g}) \leftrightarrow \mathrm{NaNO}_{3}(\mathrm{~s})+\mathrm{HCl}(\mathrm{g})$

(Reaction 2)

The substitution of $\mathrm{Cl}$ by acid anions in individual SSPs was studied by observing the elemental weight ratios of $\mathrm{Na}, \mathrm{Cl}$ and $\mathrm{S}$ in the samples. In Fig. 2, point a addresses fresh 
Table 2

Relative fractions (\%) of different particle types during the voyage

\begin{tabular}{|c|c|c|c|c|c|c|c|c|c|c|c|c|c|c|c|c|c|c|c|c|c|c|c|}
\hline Sample number & 1 & 2 & 3 & 4 & 5 & 6 & 7 & 8 & 9 & 10 & 11 & 12 & 13 & 14 & 15 & 16 & 17 & 18 & 19 & 20 & 21 & 22 & 23 \\
\hline $\mathrm{n}^{\mathrm{a}}$ & 100 & 100 & 100 & 100 & 100 & 100 & 100 & 100 & 100 & 100 & 50 & 50 & 50 & 50 & 50 & 50 & 50 & 100 & 50 & 50 & 50 & 50 & 50 \\
\hline Sea salt & 71 & 57 & 60 & 90 & 62 & 59 & 5 & 2 & 2 & 28 & 40 & 78 & 84 & 96 & 94 & 98 & 96 & 92 & 94 & 96 & 98 & 98 & 100 \\
\hline Mg-sulphate & 1 & 25 & 18 & 1 & 2 & 3 & 0 & 0 & 8 & 0 & 0 & 0 & 0 & 0 & 2 & 0 & 0 & 0 & 0 & 0 & 0 & 0 & 0 \\
\hline Ca-sulphate & 7 & 3 & 1 & 6 & 7 & 5 & 14 & 16 & 5 & 5 & 6 & 2 & 6 & 0 & 0 & 2 & 2 & 0 & 6 & 4 & 0 & 0 & 0 \\
\hline Mixed aluminosilicates and sea salt & 5 & 5 & 9 & 2 & 3 & 14 & 19 & 22 & 24 & 24 & 16 & 10 & 2 & 2 & 2 & 0 & 2 & 3 & 0 & 0 & 0 & 0 & 0 \\
\hline Aluminosilicates & 6 & 5 & 8 & 0 & 20 & 18 & 57 & 58 & 55 & 39 & 32 & 10 & 6 & 0 & 2 & 0 & 0 & 4 & 0 & 0 & 0 & 0 & 0 \\
\hline Ca-rich & 0 & 0 & 0 & 0 & 0 & 0 & 3 & 0 & 0 & 0 & 0 & 0 & 0 & 0 & 0 & 0 & 0 & 0 & 0 & 0 & 0 & 0 & 0 \\
\hline Fe-rich & 3 & 1 & 0 & 1 & 0 & 0 & 1 & 1 & 3 & 0 & 4 & 0 & 0 & 0 & 0 & 0 & 0 & 1 & 0 & 0 & 0 & 0 & 0 \\
\hline Other & 7 & 4 & 4 & 0 & 6 & 1 & 1 & 1 & 3 & 4 & 2 & 0 & 2 & 2 & 0 & 0 & 0 & 0 & 0 & 0 & 2 & 2 & 0 \\
\hline
\end{tabular}

${ }^{\mathrm{a}}$ Number of analysed particles. 

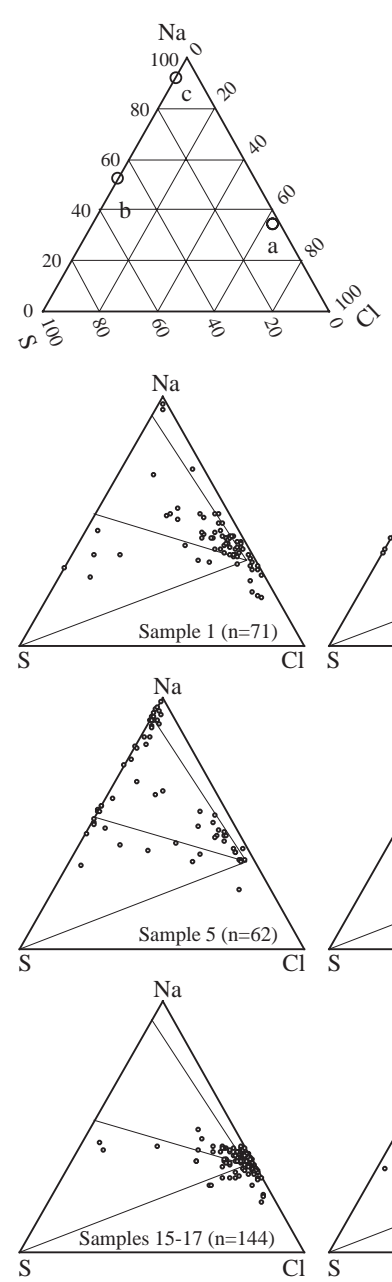
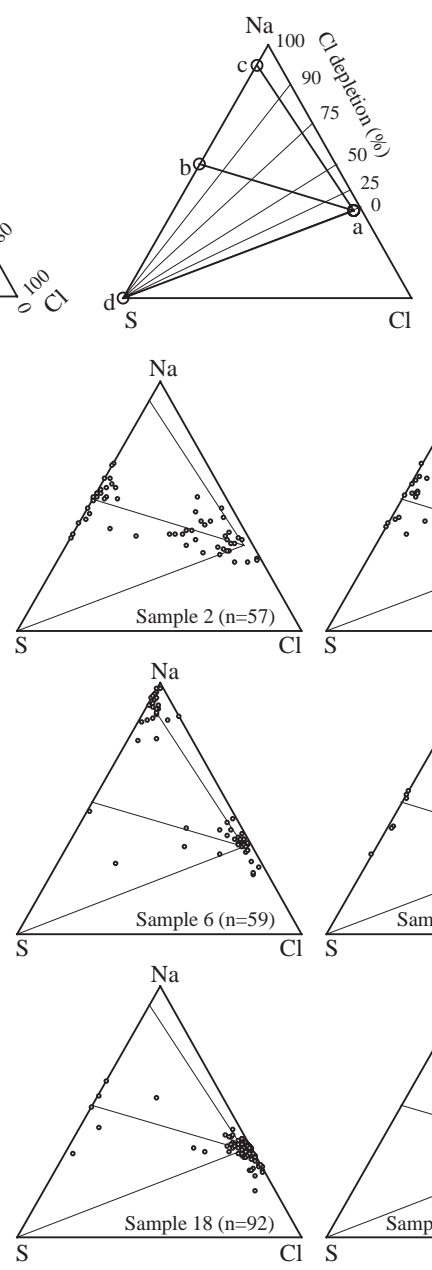

Elemental weight ratios analyzed with SEM/EDX:

\begin{tabular}{cccccccc}
\hline Point & $\mathrm{Na}$ & $\mathrm{Cl}$ & $\mathrm{S}$ & $\mathrm{Mg}$ & $\mathrm{Ca}$ & $\mathrm{K}$ & Sum \\
\hline $\mathrm{a}$ & 32.5 & 58.4 & 2.7 & 3.9 & 1.2 & 1.2 & 100 \\
$\mathrm{~b}$ & 47.8 & 0 & 42.9 & 5.7 & 1.8 & 1.8 & 100 \\
$\mathrm{c}$ & 78.1 & 0 & 6.6 & 9.4 & 3.0 & 3.0 & 100 \\
\hline
\end{tabular}

Ratios of $\mathrm{Na}, \mathrm{Cl}$ and $\mathrm{S}$ shown in ternary plots:

\begin{tabular}{ccccc}
\hline Point & $\mathrm{Na}$ & $\mathrm{Cl}$ & $\mathrm{S}$ & Sum \\
\hline $\mathrm{a}$ & 34.7 & 62.4 & 2.9 & 100 \\
$\mathrm{~b}$ & 52.7 & 0 & 47.3 & 100 \\
$\mathrm{c}$ & 92.2 & 0 & 7.8 & 100 \\
\hline
\end{tabular}
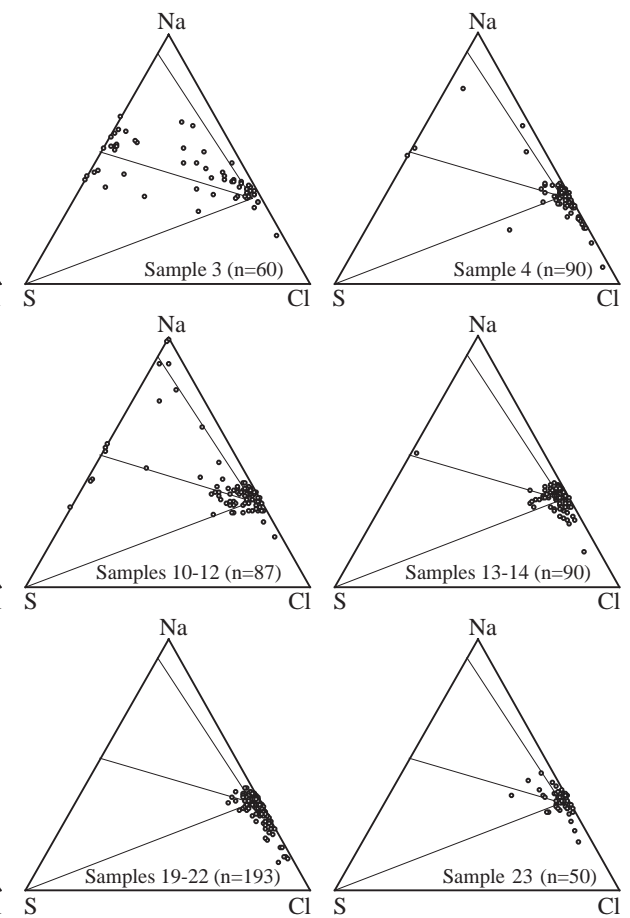

Fig. 2. Weight ratios of $\mathrm{Na}, \mathrm{Cl}$ and $\mathrm{S}$ for sea-salt particles in different samples. The reference ternary plots on the top line show scales of elemental weight rations (sum of $\mathrm{Na}, \mathrm{Cl}$ and $\mathrm{S}$ normalized to $100 \%$ ) and rate of $\mathrm{Cl}$ depletion based on $\mathrm{Cl} / \mathrm{Na}$ ratio. The selected points $\mathrm{a}, \mathrm{b}$ and $\mathrm{c}$ show following elemental ratios: (a) fresh sea salt (seawater); (b) all $\mathrm{Cl}$ of sea salt substituted by sulphate (reaction 1 in text); (c) all $\mathrm{Cl}$ of sea salt substituted by nitrate (reaction 2 in text). The lines $\mathrm{a}-\mathrm{b}$ and $\mathrm{a}-\mathrm{c}$ describe different levels of $\mathrm{Cl}$ depletion caused by the abovementioned reactions. On line $\mathrm{a}-\mathrm{d}$, the $\mathrm{Cl} / \mathrm{Na}$ ratio is the same as in fresh sea salt $(1.8)$ and there has been accumulation of S-containing compounds without $\mathrm{Cl}$ depletion. The results are semiquantitative.

sea salt, and in point $\mathrm{b}$ all $\mathrm{Cl}$ has been substituted by sulphate. The particles located above the line $\mathrm{a}-\mathrm{b}$ also contained elements (anions) that could not be measured with SEM/EDX, indicating the presence of nitrate. In point $\mathrm{c}, \mathrm{Cl}$ is totally substituted by nitrate. If particles are located below line $\mathrm{a}-\mathrm{b}$, they may contain more sulphate (e.g. ammonium sulphate $\left(\mathrm{NH}_{4}\right)_{2} \mathrm{SO}_{4}$ or ammonium bisulphate $\left.\left(\mathrm{NH}_{4}\right) \mathrm{HSO}_{4}\right)$ than are substituted in $\mathrm{Cl}$ depletion or $\mathrm{Cl}$ may be substituted by monovalent S-containing compounds such as methane sulphonic 
acid (MSA). During this voyage, $\mathrm{Cl}$ substitution by MSA was insignificant (Virkkula et al., submitted for publication-b). Analytical errors probably caused further deviation in the elemental ratios, since the results of the SEM/EDX method were semiquantitative. Table 3 summarizes numerically the rates of $\mathrm{Cl}$ substitution; these values were calculated using the $\mathrm{Cl} / \mathrm{Na}$ ratios of every single particle.

There were large differences in the modification of SSPs by acidic compounds in the samples studied (Fig. 2 and Table 3). The relative amounts of moderately and strongly modified SSPs were highest in the North Atlantic Ocean and especially near Europe (65$74 \%$ of SSPs), when air masses arrived from the direction of the continent. However, there was strong variation even in the successive samples, depending on the source areas of air masses and different meteorological conditions. In sample $1, \mathrm{Cl}$ was substituted both by nitrate and sulphate, while in samples 2 and 3, the relative fraction of sulphate was clearly higher. The results of Virkkula et al. (submitted for publication-a) confirmed that the concentrations of non-sea-salt sulphate (nss- $\mathrm{SO}_{4}^{2-}$ ) and nitrate were high in these samples. In sample 2, the concentration of nss- $\mathrm{SO}_{4}^{2-}$ was extraordinarily high $\left(\sim 4.5 \mu \mathrm{g} \mathrm{m}^{-3}\right)$, about 2.5 times higher than in any other sample during the voyage (Virkkula et al., submitted for publication-a). During the collection of sample 1, the ship was passing the English Channel and the air masses arrived from the direction of the British Isles (Fig. 1). During the collection of sample 2, air masses arrived from the directions of France and Northwestern Spain, and during the collection of sample 3 from the direction of Northwestern Spain and Portugal. The trajectories of samples 2 and 3 indicated that air masses arrived just from the direction of large power plants located in Northwestern Spain and on the coast of Portugal. These plants are among the strongest point sources of $\mathrm{S}$ in Europe (EMEP, 2001). However, the particle number concentration, wind direction and wind speed measurements showed that sample 2 and possibly part of sample 3 were contaminated by the ship's emissions (Virkkula et al., submitted for publication-a). Therefore, it is difficult to estimate how large were the proportions of $\mathrm{Cl}$ depletion caused by emission from the continent and the ship.

Sample 4 was very different from previous samples, since it contained almost nothing but fresh SSPs (91\%). It was collected in the open sea area between Portugal and the Canary Islands. Air masses arrived from the direction of Portugal and Spain and the ship was not yet far from the coast of Portugal at the beginning of sampling (Fig. 1). The main reasons for the very low fraction of modified SSPs were probably the very high sea-salt concentration in the air (Virkkula et al., submitted for publication-a), dilution of pollutants due to increasing distance from continental emission sources and unusually low RH of $51 \%$ (Virkkula et al., submitted for publication-a). The RH was occasionally even under $40 \%$ during sampling, and for that reason at least some of the SSPs were probably in

Table 3

Relative fractions (\%) of sea-salt particles with different levels of chlorine depletion

\begin{tabular}{lrrrrrrrrrrrr}
\hline Sample number & 1 & 2 & 3 & 4 & 5 & 6 & $10-12$ & $13-14$ & $15-17$ & 18 & $19-22$ & 23 \\
\hline No or minor Cl depletion $(<20 \%)$ & 34 & 26 & 35 & 91 & 13 & 44 & 66 & 90 & 80 & 85 & 99 & 86 \\
Moderate Cl depletion $(20-90 \%)$ & 60 & 31 & 38 & 6 & 31 & 14 & 21 & 9 & 19 & 10 & 1 & 14 \\
Total or strong Cl depletion $(>90 \%)$ & 6 & 43 & 27 & 3 & 56 & 42 & 13 & 1 & 1 & 5 & 0 & 0 \\
\hline
\end{tabular}

Numbers of analysed particles are shown in Fig. 2. 
crystalline form, since the crystallization RH of sea salt is $45 \%$ (Tang et al., 1997). The heterogenic reactions of SSPs with acidic gases are reduced when SSPs are in solid form (ten Brink, 1998; Hara et al., 2002).

In samples 5 and 6, the fraction of moderately or strongly modified SSPs was again high ( $87 \%$ and $56 \%$, respectively). In sample 5 , most of the SSPs contained sulphate and/ or nitrate, and in sample 6, nearly all of the modified SSPs were in the form of $\mathrm{NaNO}_{3}$. During the collection of sample 5, the ship passed the Canary Islands, and most of sample 6 was collected far past the Canary Islands, but air masses still arrived from the direction of the Canary Islands, Portugal and Spain. The amount of modified SSPs was surprisingly high, similar to that of samples collected near continental Europe. The concentrations of air pollutants and the relative amount of modified SSPs may rise in areas near the Canary Islands when air masses come from the direction of Europe (Hoornaert et al., 2003; Li et al., 2003a). However, the fraction of modified SSPs was so high that part of the N and S compounds may have originated from more closely located sources. Anthropogenic emissions from the Canary Islands could have contributed remarkably to the pollutants, especially in sample 5. Ship traffic emissions may have also affected $\mathrm{Cl}$ depletion (Song et al., 2003), since the ship was sailing on a busy sea lane between Europe, Africa and South America (Capaldo et al., 1999; Lawrence and Crutzen, 1999). Emissions of $\mathrm{NO}_{x}$ and $\mathrm{SO}_{2}$ from ocean-going ships have been estimated to be $\sim 10-14 \%$ and $\sim 3-4 \%$, respectively, of the total emissions of these species from the burning of fossil fuels (Sinha et al., 2003). Sample 6 contained abundant aluminosilicates and aluminosilicates mixed with sea salt (Table 2). The main source of aluminosilicates in this sample was the Sahara Desert (Section 3.2.2.), which indicates that emissions from continental Africa may also have affected the $\mathrm{Cl}$ depletion of SSPs.

Samples 7-9 were excluded from the sea-salt inspection because the amount of SSPs analysed was low, due to the high number of continental particles (Table 2). In samples $10-12$, the fraction of moderately and strongly modified SSPs was 34\%, and the acidic compound probably resulted partially from biomass burning, as will be discussed in Sections 3.3.1 and 3.3.2. The fraction of modified SSPs was very low in samples 13 and $14(10 \%)$ and samples $15-17(20 \%)$, clearly because these samples were collected far from the coast of Africa. Samples 18-23 were collected between Cape Town and the coast of Antarctica. Sample 18 contained 15\% moderately and strongly modified SSPs, indicating continental impact from southernmost Africa. Samples 19-22 contained practically the only fresh SSPs, and the degree of modification of sea salt in these samples was the lowest occurring in the voyage. During the collection of sample 23, the ship was sailing in the pack ice area of the Antarctic coast. The SSPs of this sample originated further from the open sea, and during transport some of them were modified slightly by acidic compounds.

Our results show that the substitution of $\mathrm{Cl}$ from sea salt by sulphate and nitrate was low at remote ocean areas and strongly increased near more polluted coastal areas. Sea salt is an important sink for gaseous species producing nss- $\mathrm{SO}_{4}^{2-}$ and nitrate as well as a source for atmospheric chlorine having thus great atmospheric implications. Nss- $\mathrm{SO}_{4}^{2-}$ and nitrate accumulated into SSPs are removed rapidly from the atmosphere due to large sizes of SSPs, which reduces the amounts of scavenged species in the atmosphere. For example, the model simulations of Gong and Barrie (2003) showed that the presence of sea salt increases the mass median diameter of sulphate aerosols by up to a factor of 2 over 
the marine boundary layer $(\mathrm{MBL})$ with high sea salt concentrations and reduces the global sulphate aerosol mass in the surface MBL from 5 to $75 \%$ depending on the sea salt distributions. This change reduces the fraction nss- $\mathrm{SO}_{4}^{2}$ aerosol as cloud condensation nuclei, which may decrease cloud droplet number concentrations over oceans changing lifetimes and optical properties of clouds (Gong and Barrie, 2003).

The modification of sea-salt particles also changes their own chemical properties such as deliquescence and re-crystallization points. These alterations influence the hygroscopicity and water content of different sea-salt particle types; e.g. $\mathrm{NaNO}_{3}$ may contain liquid water in much lower RHs than fresh sea-salt particles (Hoffman et al., 2004). Thus, the modification of SSPs may change their size (and light scattering properties) and affinity for cloud condensation nuclei formation. The presence of water on salt surfaces also greatly enhances their reactivity with gases compared with dry SSPs (ten Brink, 1998; Hara et al., 2002).

\subsubsection{Mg-sulphate particles and other fractional recrystallization products of SSPS}

In some $\mathrm{SSPs}$, the $\mathrm{Mg}, \mathrm{K}$ or $\mathrm{Ca}$ fractions differed clearly from the ratios of these elements to $\mathrm{Na}$ in seawater. The elemental ratios indicated that there were different mixed $\mathrm{Mg}, \mathrm{K}$ or Ca sulphates and chlorides, a few $\mathrm{CaCl}_{2}$ and $\mathrm{MgCl}_{2}$ and many sulphate particles, that contained mainly $\mathrm{Mg}$ or $\mathrm{Ca}$ and only minor amounts of $\mathrm{Na}$. These kinds of marine particles are formed mainly due to fractional recrystallization of SSPs (Borchert, 1965; Parungo et al., 1986). However, some of these different cation sulphate particles may also have originated from continental sources or formed through the coagulation of SSPs and continental particles containing the same elements as in seawater. Ca-sulphate particles in particular have both marine and continental sources. The marine formation mechanisms of Ca-sulphate particles include fractional recrystallization of SSPs and reactions of marine $\mathrm{CaCO}_{3}$ with $\mathrm{SO}_{2}$ in the atmosphere. Marine $\mathrm{CaCO}_{3}$ may originate from fractional recrystallization of SSPs or from marine organisms such as coccoliths (Andreae et al., 1986). It seems clear that Ca-sulphate particles originated from marine sources in remote sea areas (e.g. samples 19-20), but the highest amounts of Ca-sulphate particles near the coasts indicated clearly continental sources, as will be discussed in Section 3.3.2. In this section, we focus on the formation of $\mathrm{Mg}$-sulphate particles, since their amounts were extraordinarily high in some samples.

Most of the samples collected near the coasts of Europe and Africa (samples 1-6 and 9) contained Mg-sulphate particles (Table 2). Minor amounts of $\mathrm{K}$ and/or Na were often detected in these particles (Table 1 and Fig. 3). The typical shape of the Mg-sulphate particles was slightly angular oval (Fig. 3). Their size was mostly $1-5 \mu \mathrm{m}$, but some larger $(6-8 \mu \mathrm{m})$ particles were also observed. The mean size of the $\mathrm{Mg}$-sulphate particles was 3.4 $\mu \mathrm{m}$, which is clearly higher than the mean sizes of other particle types $(1.7-2.1 \mu \mathrm{m})$.

The fraction of Mg-sulphate particles was very high in samples 2 (25\%), $3(18 \%)$ and 9 $(8 \%)$. These samples contained the highest concentrations of nss- $\mathrm{SO}_{4}^{2-}$ during the voyage, and some possibly originated from the ship's emissions in samples 2-3 (Virkkula et al., submitted for publication-a). The SSPs also contained abundant S in samples 2 and 3, as was discussed above (Fig. 2). In remote, clean sea areas practically no Mg-sulphate particles were observed (Table 2). Therefore, the emergence of $\mathrm{Mg}$-sulphate particles was apparently connected with high concentrations of nss-SO ${ }_{4}^{2}$. However, no nss- $\mathrm{Mg}^{2+}$ was 

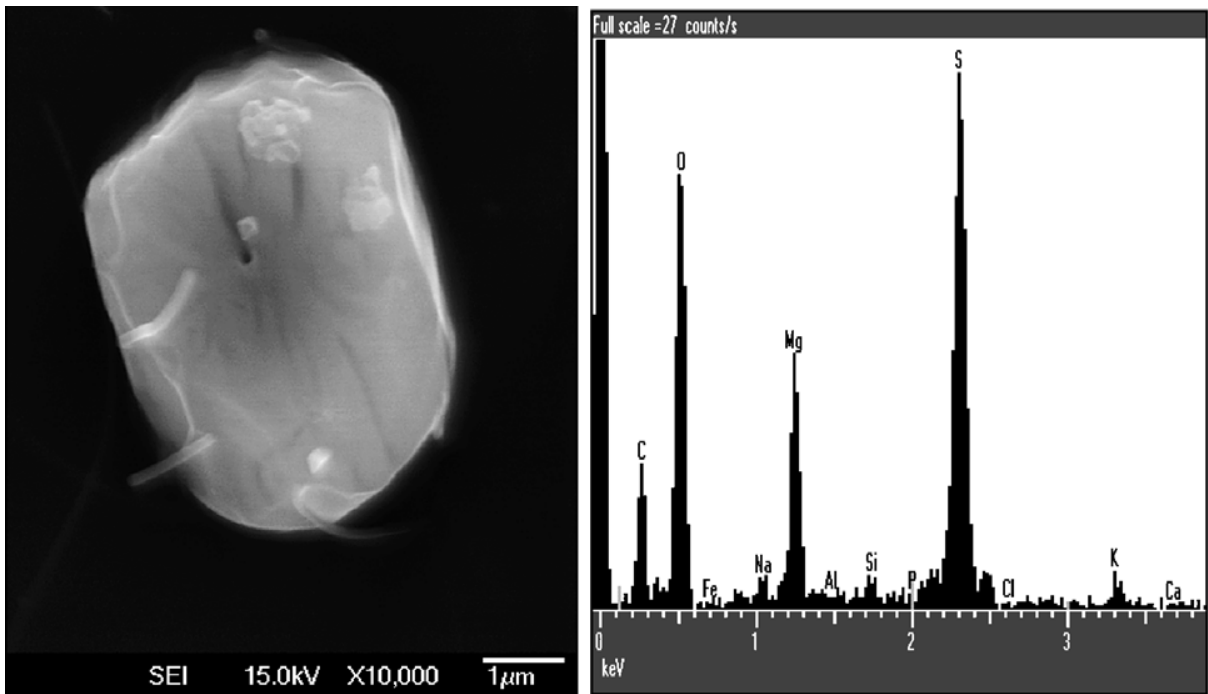

Fig. 3. SEM image and EDX spectrum of Mg-sulphate particle with minor $\mathrm{Na}$ and $\mathrm{K}$ peaks. The $\mathrm{C}$ peak arises from the adhesive tape and the Si peak from quartz filter fibres.

detected in samples 2 and 3 according to IC analysis (Virkkula et al., submitted for publication-a). This indicates that the $\mathrm{Mg}$ originated neither from the continental sources nor from the ship's emissions, or that the Mg of these particles was not water-soluble. It is difficult to find any continental sources (e.g. industry, energy production, soil dust) or ship traffic source that would produce $\mathrm{Mg}-\mathrm{S}$-rich particles that are not water-soluble. Since the continental or ship traffic source of Mg-sulphate particles seems very unlikely, we assume that the Mg-sulphate particles were formed mainly from S-rich SSPs as crystallization and fractionation products. Various crystallization products (chlorides, sulphates, nitrates and carbonates of $\mathrm{Na}^{+}, \mathrm{Mg}^{2+}, \mathrm{K}^{+}$or $\mathrm{Ca}^{2+}$ and different mixtures of these chemical components) of SSPs were observed in many studies (Parungo et al., 1986; Anderson et al., 1992, 1996; Artaxo et al., 1992; Pósfai et al., 1994; Ro et al., 2001; Li et al., 2003a). However, the fraction of Mg-sulphate particles was $18-25 \%$ in samples 2 and 3 , which is higher than in any study we have seen.

When water evaporates from seawater droplets, different compounds crystallize separately according to their solubility products (Borchert, 1965; Eugster et al., 1980; Zayani et al., 1999). After evaporation, SSPs may form aggregates of loosely attached crystals that can shatter and produce pure crystals and crystal mixtures. However, several studies addressed the question of whether crystallization and shattering has occurred before or after sampling (Parungo et al., 1986; Mouri et al., 1997; De Bock et al., 2000; Ro et al., 2001). In our case, the large size of $\mathrm{Mg}$-sulphate particles and absence of nss- $\mathrm{Mg}^{2+}$ in samples 2 and 3 suggest that they may have formed during or after sampling. If the $\mathrm{Mg}$ sulphate particles had been formed in the atmosphere, their size would have probably been smaller than other SSPs (e.g. $\mathrm{NaCl}, \mathrm{Na}_{2} \mathrm{SO}_{4}$ and $\mathrm{NaNO}_{3}$ ), since the concentration of $\mathrm{Mg}$ in sea-salt droplets is much smaller than the concentration of $\mathrm{Na}$. Coagulation of S-rich seasalt droplets on the surface of the filter during sampling, and fractional crystallization and 
shattering of these particles would also explain the absence of nss- $\mathrm{Mg}^{2+}$ in samples 2 and 3. However, we found no unusually large SSPs without Mg in these samples, which would have confirmed the formation of Mg-sulphate particles during or after sampling. Na-rich crystallization products may possibly shatter more easily than $\mathrm{Mg}$-sulphate particles. In conclusion, the fractional recrystallization of S-rich SSPs explains best the presence of $\mathrm{Mg}$-sulphate particles, but it remains uncertain whether these particles were formed before or after sampling.

Our results emphasize that although different marine crystallization products have been observed in many studies, it is still poorly understood how common these fractionally crystallized and shattered particle types are in the atmosphere and how they affect the atmospheric processes related to chemistry of sea-salt particles. As already mentioned above in the context of $\mathrm{Cl}$ depletion from SSPs, the hygroscopicity of different marine crystallization products varies, which affect both their reactivity and sizes in different RHs.

\subsection{Continental particles}

\subsubsection{Relative fractions of continental particles}

The relative fractions of particles from continental sources were calculated using following source estimates for different particle types. Pure aluminosilicates and Fe-rich particles originated totally from continental sources, because the amounts of marine elements such as $\mathrm{Na}$ and $\mathrm{Cl}$ were negligible. The total fraction of silicate particles was underestimated in our study, because pure quartz mineral particles were not analysed due to difficulties in separating them confidently from small fragments of quartz fibres from the filter material. This underestimation of the total silicate fraction is probably $\sim 10-25 \%$, based on other individual particle studies in which the transport of continental particles from Europe (Xhoffer et al., 1991; Ebert et al., 2000) and Africa (Hoornaert et al., 2003; Reid et al., 2003) to marine areas was examined.

The origin of Ca-rich particles (present only in sample 7) was very likely continental only, since they contained some $\mathrm{P}$ and the amounts of marine elements such as $\mathrm{Na}$ and $\mathrm{Cl}$ were negligible. Ca-sulphate particles originated from both continental and marine sources as discussed above, and since the fractions of these sources were impossible to distinguish, we used equal fractions as a coarse estimate. This ratio probably underestimated the fraction of continental sources when air masses arrived from the direction of the continents and overestimated continental sources in remote marine areas. Mixed aluminosilicates and sea-salt class were also divided equally between continental and marine sources. All other particle classes shown in Table 2 (SSPs, Mg-sulphate particles and 'other' particles) were considered as marine particles, although some of these particles also contained compounds that had accumulated mainly from continental sources (e.g. nss- $\mathrm{SO}_{4}^{2-}$ and $\mathrm{NO}_{3}^{-}$). The impact of continental emissions on marine particles was already discussed above.

Fig. 4 shows the relative fraction of continental particles, calculated using the abovementioned separation criteria for the particle types presented in Table 2. Virkkula et al. (submitted for publication-a) analysed the same particle samples with bulk methods. Their IC results of nss- $\mathrm{Ca}^{2+}$ and $n s s-\mathrm{K}^{+}$and activity concentrations of ${ }^{210} \mathrm{~Pb}$ are also shown in the figure for comparison. The fraction of continental particles analysed with 


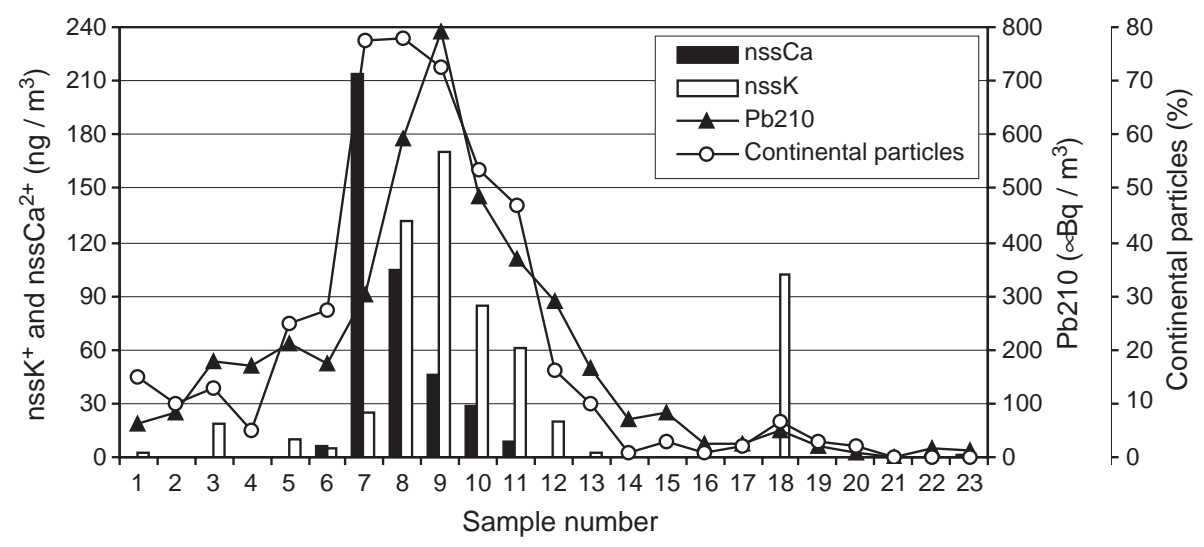

Fig. 4. Relative fraction (\%) of particles from continental sources measured with SEM/EDX. Concentrations of nss- $\mathrm{Ca}^{2+}$ and nss- $\mathrm{K}^{+}$and activity concentrations of ${ }^{210} \mathrm{~Pb}$ analysed from the same samples are also shown for comparison (Virkkula et al., submitted for publication-a).

SEM/EDX was 10-15\% near Southern Europe (samples 1-3), 5-28\% near Northwestern Africa (samples 4-6) and 47-78\% between the coast of Mauritania and Liberia (samples 7-11). In the remote sea areas west and south of Southern Africa, the fraction of continental particles was only 1-3\% (samples 14-17 and 19-20) and near Cape Town 7\% (sample 18). There were no continental particles in the remote sea areas near Antarctica (samples 21-23).

The results of nss- $\mathrm{Ca}^{2+}$ (Virkkula et al., submitted for publication-a) confirmed the high amount of continental particles in samples 6-11 (Fig. 4). Nearly all of nss- $\mathrm{Ca}^{2+}$ was in the coarse $(\mathrm{Dp}>1 \mu \mathrm{m})$ size fraction (Virkkula et al., submitted for publication-a,b). The general patterns of nss- $\mathrm{Ca}^{2+}$ concentration and the fraction of continental particles are quite similar in samples 7-11. However, the concentration of nss-Ca ${ }^{2+}$ was clearly highest in sample 7 while the relative fraction of continental particles was about equal in samples 7 and 8 according to the SEM/EDX results. One reason for this difference was the higher total amount of sea salt in sample 7 compared with the later samples 9-11 (Virkkula et al., submitted for publication-a).

Fig. 4 also shows the activity concentrations of ${ }^{210} \mathrm{~Pb}$ and concentrations of nss- $\mathrm{K}^{+}$ (Virkkula et al., submitted for publication-a). The ${ }^{210} \mathrm{~Pb}$ activity concentration can be used as a general tracer for continental air, since anthropogenic and marine sources have negligible effect on the amount of ${ }^{210} \mathrm{~Pb}$ in the atmosphere (Hotzl and Winkler, 1987; Gaggeler, 1995). The general patterns of ${ }^{210} \mathrm{~Pb}$ activity concentration and the fraction of continental particles were quite similar (Spearman coefficient of correlation $r=0.91$, $p<0.0001$ ). However, the highest value of ${ }^{210} \mathrm{~Pb}$ and also of nss- $\mathrm{K}^{+}$was in sample 9 while the fraction of nss-Ca ${ }^{2+}$ was clearly higher in samples 7 and 8 . Most of the nss- $\mathrm{K}^{+}$mass was in the submicrometre size range (Virkkula et al., submitted for publication-a,b), and the high potassium concentration in the fine size fraction is an indication of biomassburning aerosols (Andreae, 1983; Andreae et al., 1998). It is evident that the high ${ }^{210} \mathrm{~Pb}$ concentrations observed near the coast of Africa (samples 8-11) were caused by biomass burning, not wind-blown Saharan dust, since Virkkula et. al (submitted for publication-a) 
observed a strong correlation $\left(r^{2}=0.95\right)$ between ${ }^{210} \mathrm{~Pb}$ and $n s s-\mathrm{K}^{+}$but no clear correlation between ${ }^{210} \mathrm{~Pb}$ and nss- $\mathrm{Ca}^{2+}$.

\subsubsection{Sources of continental particles}

Aluminosilicates and aluminosilicates mixed with sea salt were clearly the most common continental particle types in the samples collected near the coasts of Europe and Africa (Table 2). Some Ca-sulphate and a few Fe-rich particles were also observed. The majority of aluminosilicates and Fe-rich particles were obviously soil dust, but near industrial areas some of these particles may have been fly ash from different industrial processes and fossil fuel burning. The Ca-sulphate particles also originate from various continental sources including fossil fuel burning, cement and metal industries, soil dust and biomass burning (Hoornaert et al., 1996; Li et al., 2003b). Some of the continental Ca-sulphate particles are formed from $\mathrm{CaCO}_{3}$ which had reacted with $\mathrm{SO}_{2}$ in the atmosphere. The continental $\mathrm{CaCO}_{3}$ originates from the cement and metal industries and from soil dust (Hoornaert et al., 1996). It seems clear that a significant fraction of the Ca-sulphate particles observed in the samples collected near the coasts originated from continental sources, since emissions of industrial and fossil fuel burning are high in Europe (samples 1-3), and there were Saharan dust and biomass-burning emissions near the coast of Africa.

The relative fractions of continental particles were very high $(25-78 \%)$ in the samples collected near Northern Africa (samples 5-11; Fig. 4). The potential source areas of these particles were estimated, using trajectories and NAAPS model results as well as chemical data. Both the air-mass routes and the chemical composition indicated that the origins of continental particles were different in samples 5-7 than in samples 8-11, with sample 8 showing intermediate properties (Figs. 4 and 5).

The trajectories of samples 5 and 6 came from the north, while those of sample 7 were strongly curved. The NAAPS model results indicated that there was significant Saharan dust outflow from the direction of the western Sahara and Mauritania to the sea during the collection of samples 5-7 (Fig. 5a). The ship approached the strongest dust plume near the coast of Mauritania when sample 7 was collected. The chemical composition of aluminosilicates in these samples analysed with SEM/EDX indicate wind-blown Saharan dust as the main source (Husar et al., 1997; Goudie and Middleton, 2001; Prospero et al., 2002). The relatively high amounts of Ca-sulphate particles in samples 5-8 (Table 2) and very high nss-Ca ${ }^{2+}$ concentration in sample 7 (Fig. 4) are evidence of Ca-rich minerals, such as calcite and gypsum, that are common in northern and western Sahara (Chiapello et al., 1997; Claquin et al., 1999; Goudie and Middleton, 2001).

During the collection of sample 8 air, masses arrived from the north through Senegal. The trajectories of sample 9 came first from the direction of Senegal and at the end of sampling from a more eastern route. The trajectories of samples 10 and 11 came from the direction of Nigeria. The NAAPS model results indicated that during the collection of samples $8-11$, the outflow of dust particles was quite insignificant compared with that of sample 7, and that there was large smoke plume originating from biomass-burning areas (Fig. 5b). The savanna zone located between Senegal and Sudan is one of the strongest and largest biomass-burning emission sources in the world (Liousse et al., 1996; Husar et al., 1997). The bulk chemical results of Virkkula et al. (submitted for publication-a) also 
a)

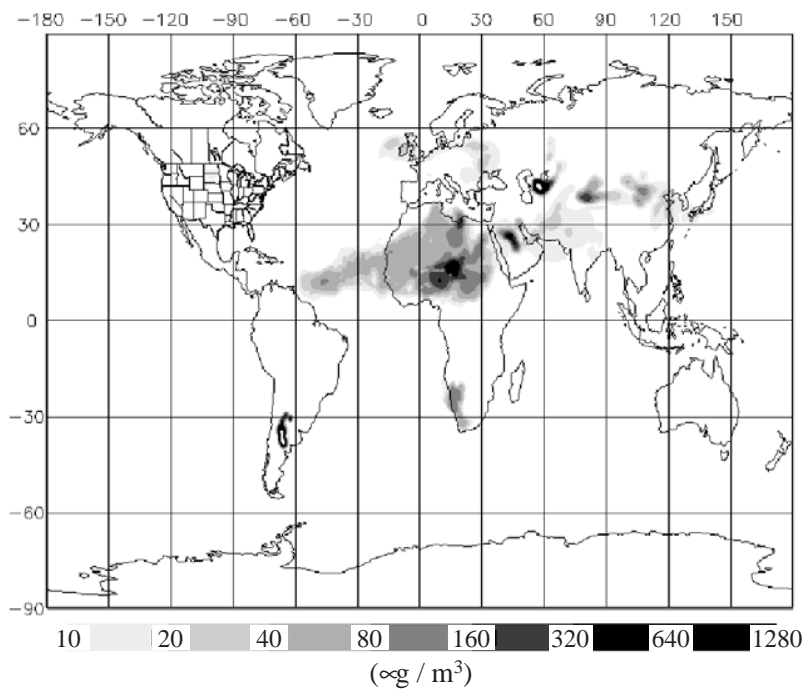

b)

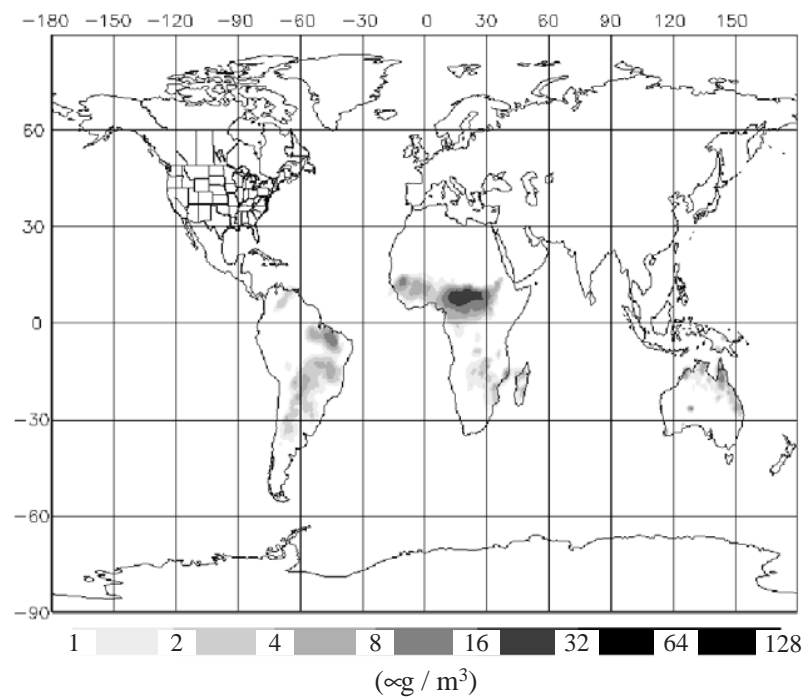

Fig. 5. NAAPS model results showing (a) surface dust concentrations for 13 November 1999 18:00 (UTC) and (b) smoke concentrations for 16 November 12:00 (UTC) (Naval Research Laboratory, Monterey, CA, website at http://www.nrlmry.navy.mil/aerosol).

showed that samples $8-11$ contained abundant nss- $\mathrm{K}^{+}$which indicated biomass burning as the major source of these aerosols (Fig. 4).

The continental smoke and aluminosilicate aerosols were mixed both with sea salt and continental gaseous compounds during their transport to the oceanic sampling sites. The 

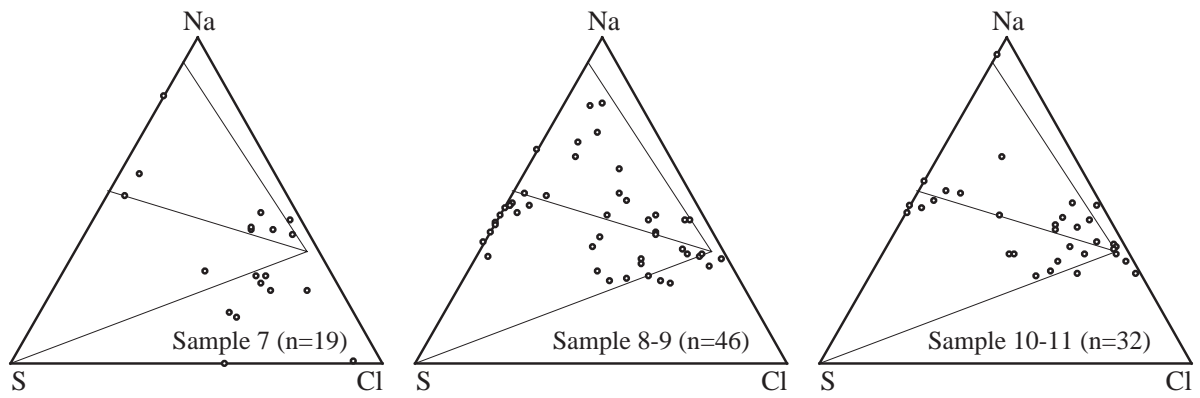

Fig. 6. Weight ratios of $\mathrm{Na}, \mathrm{Cl}$ and $\mathrm{S}$ for mixed aluminosilicates and sea-salt particles in samples 7-11.

accumulation of gaseous emission oxidation products was examined by comparing the elemental ratios of $\mathrm{Na}, \mathrm{Cl}$ and $\mathrm{S}$ in mixed aluminosilicate and sea-salt particles. The depletion of $\mathrm{Cl}$ and accumulation of $\mathrm{S}$ was clearly highest in samples 8-9 when the biomass-burning plume was strongest (Fig. 6), suggesting an interaction between coarse particles and gaseous emissions from biomass burning.

Our results show that the fractions of continental particles over the ocean were high near the coast of Europe and especially near Northern Africa. Thus, large amounts of particles are deposited to these coastal, biologically active waters. Nutrients derived from continental aerosols are important factors affecting primary productivity in oceans; e.g. atmospheric deposition of particles is a significant source of Fe in oceans (Martin et al., 1994; Sarthou et al., 2003).

The transport of continental particles over oceans has also strong climatological effects. The transport of mineral dust from Northern Africa to ocean was strong during the voyage, and Chiapello et al. (1999) observed that African dust controls the total aerosol optical depth over these sea areas (at Sal Island, Cape Verde) even in the absence of dust outbreak during winter time. Some continental particle types (Fe-rich particles and some aluminosilicates) contained abundant $\mathrm{Fe}$, which is (in its oxidized form) especially a strong light absorber (Sokolik and Toon, 1999). Most of the studied aluminosilicates contained at least some $\mathrm{S}$ (see Table 1) and $\mathrm{CaCO}_{3}$ particles were nearly totally absent. The $\mathrm{S}$ content of aluminosilicates in soil is very low, and Saharan dust contains also $\mathrm{CaCO}_{3}$ (Claquin et al., 1999). Thus, it seems likely there has been accumulation of sulphate on the surfaces of aluminosilicates and substitution of carbonate by sulphate from $\mathrm{CaCO}_{3}$ particles. This emphasizes the importance of the surface reactions on continental particles, which may change their own properties as well as affect the concentrations of other climatologically important chemical components of the atmosphere (Song and Carmichael, 1999; Galy-Lacaux et al., 2001).

\section{Summary and conclusions}

Aerosol samples were collected in the Atlantic marine boundary layer between Europe and Antarctica. The composition of coarse (aerodynamic diameter $\sim 1-3 \mu \mathrm{m}$ ) individual aerosol particles was studied using the SEM/EDX method. The SEM/EDX results showed 
that there was wide internal variation in particle samples, which could not be detected with bulk methods. The major particle types we observed were fresh sea salt, sea-salt particles reacted partly or totally with sulphuric acid or nitric acid, $\mathrm{Mg}$-sulphate, Ca-sulphate, mixed aluminosilicates and sea salt, aluminosilicates, Ca-rich particles and Fe-rich particles. The composition of individual SSPs varied strongly, depending on the rate of $\mathrm{Cl}$ depletion, and various fractional crystallization products of sea salt were also observed.

The continental impact on particles varied substantially, depending on the distance of different emission sources and on the meteorological situation. During the passage from Western Europe, a moderate or strong depletion of $\mathrm{Cl}$ in SSPs was observed. It was caused by nss- $\mathrm{SO}_{4}^{2-}$ and nitrate emissions from continental sources and possibly also from the ship. The fraction of Mg-sulphate particles was high (18-25\%) in 2 samples near Europe. Mg-sulphate particles were probably formed as a result of fractional recrystallization of SSPs in which $\mathrm{Cl}$ was substituted by sulphate. It remained unclear whether these particles were formed in the atmosphere or during and after sampling. 'European' samples also contained some aluminosilicates as well as internally mixed aluminosilicates and sea salt (total 10-17\%) originated mainly from soil dust or from emissions of industrial and power plants. These particle types were most common near the coast of Northern Africa and first originated predominantly from the Saharan dust. Later, the impact of biomass burning might have increased. Sulphate and nitrate from biomass burning and other continental sources increased $\mathrm{Cl}$ depletion in SSPs near the Gulf of Guinea. The continental impact decreased strongly farther from the coast of Western Africa where $>90 \%$ of the particles were sea salt with relatively low rates of $\mathrm{Cl}$ substitution. During the voyage between South Africa and Antarctica, the SSP fraction was almost $100 \%$, with almost no $\mathrm{Cl}$ substitution.

\section{Acknowledgements}

The project was funded by the Academy of Finland (Antarctic Research, contracts no. 43928 and 53669) and by Helsinki University Environmental Research Center. We would like to thank our colleagues at the following institutes for their collaboration during the work: Kari Lounatmaa (Helsinki University of Technology), Kaarle Kupiainen (Nordic Envicon) and Mika Räisänen (University of Helsinki, Department of Geology). The authors gratefully acknowledge the NOAA Air Resources Laboratory (ARL) for the provision of the HYSPLIT transport and dispersion model and READY website (http://www.arl.noaa.gov/ ready.html) used in this publication. The Naval Research Laboratory is acknowledged for the NAAPS model results (website at http://www.nrlmry.navy.mil/aerosol) used in this article.

\section{References}

Anderson, J.R., Buseck, P.R., Saucy, D.A., Pacyna, J.M., 1992. Characterization of individual fine-fraction particles from the Arctic aerosol at Spitsbergen, May-June 1987. Atmos. Environ. 26 (A9), 1747-1762.

Anderson, J.R., Buseck, P.R., Patterson, T.L., Arimoto, R., 1996. Characterization of the Bermuda tropospheric aerosol by combined individual-particle and bulk-aerosol analysis. Atmos. Environ. 30 (2), 319-338. 
Andreae, M.O., 1983. Soot carbon and excess fine potassium: long-range transport of combustion derived aerosols. Science 220 (4602), $1148-1151$.

Andreae, M.O., Charlson, R.J., Bruynseels, F., Storms, H., VanGrieken, R., Maenhaut, W., 1986. Internal mixture of sea salt, silicates, and excess sulfate in marine aerosols. Science 232 (4758), 1620-1623.

Andreae, M.O., Andreae, T.W., Annegarn, H., Beer, J., Cachier, H., le Canut, P., Elbert, W., Maenhaut, W., Salma, I., Wienhold, F.G., Zenker, T., 1998. Airborne studies of aerosol emissions from savanna fires in southern Africa: 2. Aerosol chemical composition. J. Geophys. Res. 103 (D24), 32119-32128.

Artaxo, P., Rabello, M.L.C., Maenhaut, W., Van Grieken, R., 1992. Trace-elements and individual particle analysis of atmospheric aerosols from the Antarctic Peninsula. Tellus 44 (B4), 318-334.

Borchert, H., 1965. Principles of oceanic salt deposition and metamorphism. In: Riley, J.P., Skirrow, G. (Eds.), Chemical Oceanography, vol. 2. Academic Press, London, pp. 205-276.

Breed, C.A., Arocena, J.M., Sutherland, D., 2002. Possible sources of PM10 in Prince George (Canada) as revealed by morphology and in situ chemical composition of particulate. Atmos. Environ. 36 (10), 1721-1731.

Capaldo, K., Corbett, J.J., Kasibhatla, P., Fischbeck, P., Pandis, S.N., 1999. Effects of ship emissions on sulphur cycling and radiative climate forcing over the ocean. Nature 400 (6746), 743-746.

Carrico, C.M., Kus, P., Rood, M.J., Quinn, P.K., Bates, T.S., 2003. Mixtures of pollution, dust, sea salt, and volcanic aerosol during ACE-Asia: radiative properties as a function of relative humidity. J. Geophys. Res. 108 (D23), 8650.

Chiapello, I., Bergametti, G., Chatenet, B., Bousquet, P., Dulac, F., Soares, E.S., 1997. Origins of African dust transported over the northeastern tropical Atlantic. J. Geophys. Res. 102 (D12), 13701-13709.

Chiapello, I., Bergametti, G., Chatenet, B., Dulac, F., Jankowiak, I., Liousse, C., Soares, E.S., 1999. Contribution of the different aerosol species to the aerosol mass load and optical depth over the northeastern tropical Atlantic. J. Geophys. Res. 104 (D4), 4025-4035.

Claquin, T., Schulz, M., Balkanski, Y.J., 1999. Modeling the mineralogy of atmospheric dust sources. J. Geophys. Res. 104 (D18), 22243-22256.

De Bock, L.A., Joos, P.E., Noone, K.J., Pockalny, R.A., VanGrieken, R.E., 2000. Single particle analysis of aerosols, observed in the marine boundary layer during the Monterey Area Ship Tracks Experiment (MAST), with respect to cloud droplet formation. J. Atmos. Chem. 37 (3), 299-329.

Dentener, F.J., Carmichael, G.R., Zhang, Y., Lelieveld, J., Crutzen, P.J., 1996. Role of mineral aerosol as a reactive surface in the global troposphere. J. Geophys. Res. 101 (D17), 22869-22889.

Draxler, R.R., Rolph, G.D., 2003. HYSPLIT (HYbrid Single-Particle Lagrangian Integrated Trajectory). Model access via NOAA ARL READY Website (http://www.arl.noaa.gov/ready/hysplit4.html). NOAA Air Resources Laboratory, Silver Spring, MD.

Ebert, M., Weinbruch, S., Hoffmann, P., Ortner, H.M., 2000. Chemical characterization of North Sea aerosol particles. J. Aerosol Sci. 31 (5), 613-632.

Ebert, M., Weinbruch, S., Rausch, A., Gorzawski, G., Hoffmann, P., Wex, H., Helas, G., 2002. Complex refractive index of aerosols during LACE 98 as derived from the analysis of individual particles. J. Geophys. Res. 107 (D21), 8121.

EMEP, 2001. Transboundary acidification and eutrophication and ground level ozone in Europe. Joint CIAM and CCC and MSC-W report. EMEP Summary Report 1/2001. URL http://www.emep.int/reports/ EMEP_Report_1_2001.pdf.

Eugster, H.P., Harvie, C.E., Weare, J.H., 1980. Mineral equilibria in a 6-component seawater system, Na-K-MgCa-SO4-Cl-H2O, at 25-degrees-C. Geochim. Cosmochim. Acta 44 (9), 1335-1347.

Gaggeler, H.W., 1995. Radioactivity in the atmosphere. Radiochim. Acta 70-1, 345-353.

Galy-Lacaux, C., Carmichael, G.R., Song, C.H., Lacaux, J.P., Al Ourabi, H., Modi, A.I., 2001. Heterogeneous processes involving nitrogenous compounds and Saharan dust inferred from measurements and model calculations. J. Geophys. Res., D: Atmos. 106 (D12), 12559-12578.

Gao, Y., Anderson, J.R., 2001. Characteristics of Chinese aerosols determined by individual-particle analysis. J. Geophys. Res. 106 (D16), 18037-18045.

Gong, S.L., Barrie, L.A., 2003. Simulating the impact of sea salt on global nss sulphate aerosols. J. Geophys. Res., D: Atmos. 108 (D16), 4516.

Goudie, A.S., Middleton, N.J., 2001. Saharan dust storms: nature and consequences. Earth-Sci. Rev. 56 (1-4), $179-204$ 
Hara, K., Osada, K., Nishita, C., Yamagata, S., Yamanocuhi, T., Herber, A., Matsunaga, K., Iwasaka, Y., Nagatani, M., Nakata, H., 2002. Vertical variations of sea-salt modification in the boundary layer of spring Arctic during the ASTAR 2000 campaign. Tellus 54 (B4), 361-376.

Hoffman, R.C., Laskin, A., Finlayson-Pitts, B.J., 2004. Sodium nitrate particles: physical and chemical properties during hydration and dehydration, and implications for aged sea salt aerosols. J. Aerosol Sci. 35 (7), 869-887.

Hoornaert, S., Van Malderen, H., Van Grieken, R., 1996. Gypsum and other calcium-rich aerosol particles above the North Sea. Environ. Sci. Technol. 30 (5), 1515-1520.

Hoornaert, S., Godoi, R.H.M., Van Grieken, R., 2003. Single particle characterisation of the aerosol in the marine boundary layer and free troposphere over Tenerife, NE Atlantic, during ACE-2. J. Atmos. Chem. 46 (3), $271-293$.

Hotzl, H., Winkler, R., 1987. Activity concentrations of Ra-226, Ra-228, Pb-210, K-40 and Be-7 and their temporal variations in surface air. J. Environ. Radioact. 5 (6), 445-458.

Husar, R.B., Prospero, J.M., Stowe, L.L., 1997. Characterization of tropospheric aerosols over the oceans with the NOAA advanced very high resolution radiometer optical thickness operational product. J. Geophys. Res. 102 (D14), 16889-16909.

IPCC, 2001. Climate Change 2001-The Scientific Basis. Cambridge University Press, New York.

Kaufman, Y.J., Tanré, D., Boucher, O., 2002. A satellite view of aerosols in the climate system. Nature 419 (6903), 215-223.

Kerminen, V.M., Teinilä, K., Hillamo, R., Pakkanen, T., 1998. Substitution of chloride in sea-salt particles by inorganic and organic anions. J. Aerosol Sci. 29 (8), 929-942.

Koponen, I.K., Virkkula, A., Hillamo, R., Kerminen, V.M., Kulmala, M., 2002. Number size distributions and concentrations of marine aerosols: observations during a cruise between the English Channel and the coast of Antarctica. J. Geophys. Res. 107 (D24), 4753.

Kupiainen, K., Tervahattu, H., Räisänen, M., 2003. Experimental studies about the impact of traction sand on urban road dust composition. Sci. Total Environ. 308 (1-3), 175-184.

Laskin, A., Gaspar, D.J., Wang, W.H., Hunt, S.W., Cowin, J.P., Colson, S.D., Finlayson-Pitts, B.J., 2003. Reactions at interfaces as a source of sulfate formation in sea-salt particles. Science 301 (5631), 340-344.

Lawrence, M.G., Crutzen, P.J., 1999. Influence of NOx emissions from ships on tropospheric photochemistry and climate. Nature 402 (6758), 167-170.

Li, J., Anderson, J.R., Buseck, P.R., 2003a. TEM study of aerosol particles from clean and polluted marine boundary layers over the North Atlantic. J. Geophys. Res. 108 (D6), 4189.

Li, J., Pósfai, M., Hobbs, P.V., Buseck, P.R., 2003b. Individual aerosol particles from biomass burning in southern Africa: 2. Compositions and aging of inorganic particles. J. Geophys. Res. 108 (D13), 8484.

Liousse, C., Penner, J.E., Chuang, C., Walton, J.J., Eddleman, H., Cachier, H., 1996. A global three-dimensional model study of carbonaceous aerosols. J. Geophys. Res. 101 (D14), $19411-19432$.

Martin, J.H., Coale, K.H., Johnson, K.S., Fitzwater, S.E., Gordon, R.M., Tanner, S.J., Hunter, C.N., Elrod, V.A., Nowicki, J.L., Coley, T.L., Barber, R.T., Lindley, S., Watson, A.J., Vanscoy, K., Law, C.S., Liddicoat, M.I., Ling, R., Stanton, T., Stockel, J., Collins, C., Anderson, A., Bidigare, R., Ondrusek, M., Latasa, M., Millero, F.J., Lee, K., Yao, W., Zhang, J.Z., Friederich, G., Sakamoto, C., Chavez, F., Buck, K., Kolber, Z., Greene, R., Falkowski, P., Chisholm, S.W., Hoge, F., Swift, R., Yungel, J., Turner, S., Nightingale, P., Hatton, A., Liss, P., Tindale, N.W., 1994. Testing the iron hypothesis in ecosystems of the equatorial Pacific-Ocean. Nature 371 (6493), 123-129.

Mouri, H., Nagao, I., Okada, K., Koga, S., Tanaka, H., 1997. Elemental compositions of individual aerosol particles collected over the Southern Ocean: a case study. Atmos. Res. 43 (2), 183-195.

Mouri, H., Nagao, I., Okada, K., Koga, S., Tanaka, H., 1999. Individual-particle analyses of coastal Antarctic aerosols. Tellus 51 (3B), 603-611.

Paoletti, L., De Berardis, B., Diociaiuti, M., 2002. Physico-chemical characterisation of the inhalable particulate matter (PM10) in an urban area: an analysis of the seasonal trend. Sci. Total Environ. 292 (3), 265-275.

Parungo, F.P., Nagamoto, C.T., Harris, J.M., 1986. Temporal and spatial variations of marine aerosols over the Atlantic Ocean. Atmos. Res. 20, 23-37.

Pósfai, M., Anderson, J.R., Buseck, P.R., Shattuck, T.W., Tindale, N.W., 1994. Constituents of a remote Pacific marine aerosol—a TEM Study. Atmos. Environ. 28 (10), 1747-1756. 
Pósfai, M., Anderson, J.R., Buseck, P.R., Sievering, H., 1995. Compositional variations of sea-salt-mode aerosolparticles from the North-Atlantic. J. Geophys. Res. 100 (D11), 23063-23074.

Prospero, J.M., Ginoux, P., Torres, O., Nicholson, S.E., Gill, T.E., 2002. Environmental characterization of global sources of atmospheric soil dust identified with the Nimbus 7 Total Ozone Mapping Spectrometer (TOMS) absorbing aerosol product. Rev. Geophys. 40 (1), 1002.

Raes, F., Bates, T., McGovern, F., Van Liedekerke, M., 2000. The 2nd aerosol characterization experiment (ACE-2): general overview and main results. Tellus 52 (B2), 111-125.

Reid, E.A., Reid, J.S., Meier, M.M., Dunlap, M.R., Cliff, S.S., Broumas, A., Perry, K., Maring, H., 2003. Characterization of African dust transported to Puerto Rico by individual particle and size segregated bulk analysis. J. Geophys. Res. 108 (D19), 8591.

Ro, C.U., Oh, K.Y., Kim, H., Kim, Y.P., Lee, C.B., Kim, K.H., Kang, C.H., Osan, J., De Hoog, J., Worobiec, A., Van Grieken, R., 2001. Single-particle analysis of aerosols at Cheju Island, Korea, using low-Z electron probe X-ray microanalysis: a direct proof of nitrate formation from sea salts. Environ. Sci. Technol. 35 (22), 4487-4494.

Rojas, C.M., Van Grieken, R.E., 1992. Electron-microprobe characterization of individual aerosol-particles collected by aircraft above the southern bight of the North-Sea. Atmos. Environ. 26 (A7), 1231-1237.

Rolph, G.D., 2003. Real-time Environmental Applications and Display sYstem (READY) Website (http:// www.arl.noaa.gov/ready/hysplit4.html). NOAA Air Resources Laboratory, Silver Spring, MD.

Sarthou, G., Baker, A.R., Blain, S., Achterberg, E.P., Boye, M., Bowie, A.R., Croot, P., Laan, P., de Baar, H.J.W., Jickells, T.D., Worsfold, P.J., 2003. Atmospheric iron deposition and sea-surface dissolved iron concentrations in the eastern Atlantic Ocean. Deep-sea Res., Part 1, Oceanogr. Res. Pap. 50 (10-11), 1339-1352.

Sinha, P., Hobbs, P.V., Yokelson, R.J., Christian, T.J., Kirchstetter, T.W., Bruintjes, R., 2003. Emissions of trace gases and particles from two ships in the southern Atlantic Ocean. Atmos. Environ. 37 (15), 2139-2148.

Sokolik, I.N., Toon, O.B., 1999. Incorporation of mineralogical composition into models of the radiative properties of mineral aerosol from UV to IR wavelengths. J. Geophys. Res., D: Atmos. 104 (D8), 9423-9444.

Song, C.H., Carmichael, G.R., 1999. The aging process of naturally emitted aerosol (sea-salt and mineral aerosol) during long range transport. Atmos. Environ. 33 (14), 2203-2218.

Song, C.H., Chen, G., Davis, D.D., 2003. Chemical evolution and dispersion of ship plumes in the remote marine boundary layer: investigation of sulfur chemistry. Atmos. Environ. 37 (19), 2663-2679.

Tang, I.N., Tridico, A.C., Fung, K.H., 1997. Thermodynamic and optical properties of sea salt aerosols. J. Geophys. Res. 102 (D19), 23269-23275.

Tanre, D., Haywood, J., Pelon, J., Leon, J.F., Chatenet, B., Formenti, P., Francis, P., Goloub, P., Highwood, E.J., Myhre, G., 2003. Measurement and modeling of the Saharan dust radiative impact: overview of the Saharan Dust Experiment (SHADE). J. Geophys. Res. 108 (D18), 8574.

ten Brink, H.M., 1998. Reactive uptake of HNO3 and H2SO4 in sea-salt (NaCl) particles. J. Aerosol Sci. 29 (1-2), 57-64.

Virkkula, A., Teinilä, K., Hillamo, R., Kerminen, V.-M., Saarikoski, S., Aurela, M., Viidanoja, J., Paatero, J., Koponen, I.K., Kulmala, M., Niemi, J.V., submitted for publication-a. Chemical composition of boundary layer aerosol over the Atlantic Ocean and at an Antarctic site: Part 1. Concentrations. J. Geophys. Res.

Virkkula, A., Teinilä, K., Hillamo, R., Kerminen, V.-M., Saarikoski, S., Aurela, M., Koponen, I.K., Kulmala, M., submitted for publication-b. Chemical composition of boundary layer aerosol over the Atlantic Ocean and at an Antarctic site: Part 2. Size distributions. J. Geophys. Res.

Xhoffer, C., Bernard, P., Vangrieken, R., Vanderauwera, L., 1991. Chemical characterization and source apportionment of individual aerosol-particles over the North-Sea and the English-Channel using multivariate techniques. Environ. Sci. Technol. 25 (8), 1470-1478.

Zayani, L., Rokbani, R., Trablesi-Ayedi, M., 1999. Study of the evaporation of a brine involving the system Na+, $\mathrm{Mg} 2+, \mathrm{K}+, \mathrm{Cl}-, \mathrm{S} 42-\mathrm{H} 2 \mathrm{O}$ - crystallisation of oceanic salts. J. Therm. Anal. Calorim. 57 (2), 575-585.

Zhang, D.Z., Iwasaka, Y., Shi, G.Y., Zang, J.Y., Matsuki, A., Trochkine, D., 2003. Mixture state and size of Asian dust particles collected at southwestern Japan in spring 2000. J. Geophys. Res. 108 (D24). 